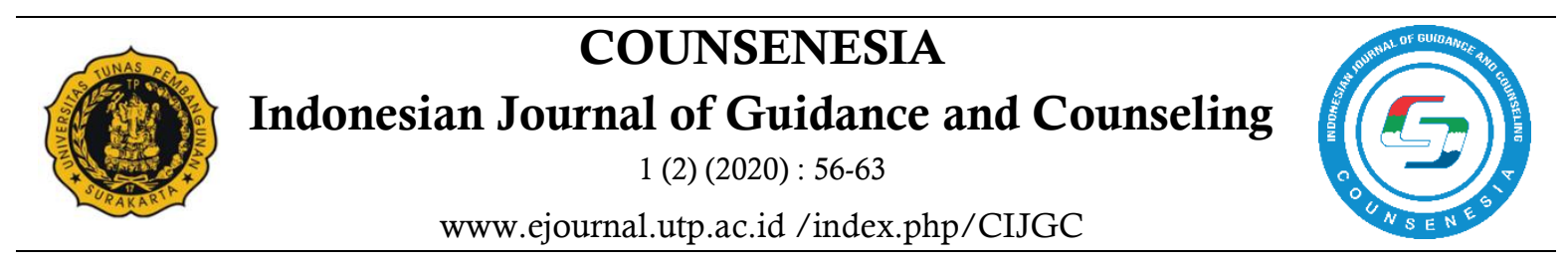

\title{
KEEFEKTIFAN KONSELING KELOMPOK TEKNIK BEHAVIOR CONTRACT UNTUK MENGURANGI GEJALA-GEJALA KECANDUAN SMARTPHONE
}

\author{
Tera Pertiwi Atikah ${ }^{1}$, Sugiyo $^{2}$ \\ 1,2 Universitas Negeri Semarang \\ E-mail: tera.pertiwi@gmail.com ${ }^{1}$
}

\begin{abstract}
Info Artikel
Abstrak

Riwayat Artikel

$\overline{\text { Tujuan penelitian ini yaitu untuk mengetahui keefektifan konseling kelompok teknik }}$

Diterima:

behavior contract untuk mengurangi gejala-gejala kecanduan smartphone. Jenis

November 2020 penelitian ini merupakan penelitian eksperimen dengan desain one group pretest-

Disetujui:

Desember 2020 posttest. Teknik pengambilan sampel purposive sampling. Instrument pengumpulan data yang digunakan skala kecanduan smartphone. Validitas diuji dengan rumus Publikasi:

Desember 2020 Product moment dan dengan koefesien reliabilitas 0,936. Teknik analisis data yang digunakan analisis deskripstif persentase dan analisis uji wilcoxon. Berdasarkan hasil uji uji wilcoxon $(\mathrm{Z}=-2,366$, $p<0,05)$ menunjukkan bahwa adanya penurunan gejalagejala kecanduan smartphone siswa sesudah diberikan perlakuan secara signifikan, penurunan rata-rata sebesar $18,18 \%$. Hal ini menunjukkan bahwa konseling kelompok teknik behavior contract terbukti efektif untuk mengurangi gejala-gejala kecanduan smartphone pada siswa. Selanjutnya, konselor sekolah dapat menerapkan dan mengembangkan konseling kelompok dengan teknik behavior contract sebagai salah satu strategi alternatif untuk mengurangi gejala-gejala kecanduan smartphone siswa.
\end{abstract}

Kata kunci: Kecanduan smartphone, konseling kelompok, teknik behavior contract

\section{Abstrac}

The purpose of this study was to determine the effectiveness of the behavior contract technique group counseling to reduce the symptoms of smartphone addiction. This type of research is an experimental study with a one group pretest-posttest design. The sampling technique was purposive sampling. The data collection instrument used was the smartphone addiction scale. Validity was tested with the Product moment formula and with a reliability coefficient of 0.936 . The data analysis technique used percentage descriptive analysis and Wilcoxon test analysis. Based on the results of the Wilcoxon test $(Z=-2.366, p<0.05)$, it showed that there was a significant decrease in the symptoms of student smartphone addiction after being given treatment, the average decrease was $18.18 \%$. This shows that the behavior contract technique group counseling is proven to be effective in reducing the symptoms of smartphone addiction in students. Furthermore, school counselors can apply and develop group counseling with the behavior contract technique as an alternative strategy to reduce the symptoms of student smartphone addiction.

Key Word: smartphone addiction, group counseling, behavior contract technique 


\section{PENDAHULUAN}

Remaja atau biasa dikenal dengan masa adolenscence yaitu tumbuh menjadi dewasa atau adaptif dari perkembangan kepribadian, berada pada fase mencoba-coba (Alwisol, 2007). Keingintahuan yang tinggi, menjadikan para remaja terus mencoba berbagai fitur smartphone yang ada, sehingga penggunaan smartphone semakin meningkat. Menurut Iskandar (2011) motif remaja dalam menggunakan smartphone cukup beragam, antara lain karena kecanggihan fitur, akses internet yang cepat, kemudahan dalam mengakses sosial media, sarana hiburan dan membantu dalam mengerjakan tugas sekolah.

Penggunaan smartphone yang dilakukan oleh remaja merupakan salah satu upaya pengalihan stress (Kurniawan, 2013). Kurniawan (2013) juga menambahkan bahwa pengalihan stres tersebut hanya bersifat sementara dan jika individu gagal untuk membatasi penggunaan akan mendapatkan akibat yang tidak diinginkan. Saat pengguna sudah tidak dapat mengontrol dirinya lagi dalam penggunaan smartphone, pengguna akan mengalami perilaku kecanduan atau adiksi pada smartphone. Hal tersebut diakui bahwa pada masa remaja adalah masa rentan ketagihan. Warger Antony (dalam Jeewon, 2016) menyatakan bahwa sebagian besar individu yang menderita penyakit kecanduan adalah mereka pada usia remaja. Menurut Kwon, Kim, Cho \& Yang (2013) seseorang yang mengalami kecanduan memiliki aspek-aspek sebagai berikut: (1) Daily life disturbance (2) Positive anticipation; (3) Withdrawal (4) Cyberspace-oriented relationship; (5) Overuse (6) Tolerance.

Studi pendahuluan dengan membagikan kuesoner skala kecanduan smartphone yang melibatkan 127 siswa kelas VIII menunjukkan bahwa rata-rata skor siswa 136,05 atau $68,02 \%$, yang artinya siswa dalam kategori tinggi. Rincian dari data tersebut yaitu ada 2 siswa kategori sangat tinggi, 64 siswa kategori tinggi, 57 siswa dalam kategori sedang dan 4 siswa dalam kategori rendah.

Robert Kaunt (dalam Sparks, 2013) menjelaskan bahwa semakin sering anggota keluarga menggunakan internet, maka mereka semakin terisolasi dari lingkungannya. Begitupula yang dialami oleh siswa, bahwa mereka mulai menarik diri dari lingkungan sekitar dengan tidak peduli terhadap teman di sekolah dan lebih suka menyendiri. Penarikan diri dari lingkungan sekitar dapat membuat siswa akan kesusahan beradaptasi dengan lingkungan dan merasa nyaman menyendiri bersama smartphone yang mereka miliki. Hal tersebut membuat siswa sulit untuk mengembangkan dirinya.

Berdasarkan dengan masalah yang terjadi di lapangan, perilaku siswa tersebut merupakan bentuk gejala kecanduan smartphone. Apabila gejala-gejala kecanduan smartphone tersebut dibiarkan akan berdampak negatif bagi kehidupan siswa di masa sekarang dan di masa yang akan datang. Resiko kecanduan smartphone menunjukkan adanya tingkat masalah perilaku dan emosional yang lebih parah, harga diri yang rendah, dan kualitas komunikasi yang lebih buruk dengan lingkungan sekitar (Jeewon, 2016). Masruri (2011) berpendapat bahwa kecanduan smartphone dapat menyebabkan gangguan tidur, memicu kecemasan, menyebabkan otak melemah, gaya hidup yang boros, menumpulkan kepekaan sosial, easy going (sikap tidak peduli terhadap masa depan), dan mengganggu moralitas penggunanya.

Berdasarkan hal tersebut, perlu adanya strategi bantuan pada siswa dalam mereduksi gejala-gejala kecanduan smartphone yang ada supaya berkurang secara efektif. Adapun layanan yang digunakan dalam penelitian ini adalah layanan dalam format kelompok, yaitu konseling kelompok. Konseling kelompok menurut Wibowo (2015) layanan 
konseling kelompok adalah suatu proses interpersonal yang dinamis yang menitik beratkan pada kesadaran berpikir dan tingkah laku, melibatkan fungsi terapeutis, berorientasi pada kenyataan, ada rasa saling percaya mempercayai, ada pengertian, penerimaan dan bantuaan.. Salah satu pendekatan dalam konseling yaitu pendekatan behavior. Pendekatan behavior adalah suatu pandangan ilmiah tentang tingkah laku manusia. Menurut Corey (2005) terapi behavior diarahkan pada tujuan untuk memperoleh tingkah laku baru dan penghapusan tingkah laku yang maladaptif.

Pendekatan behavior dipilih karena pendekatan ini mempunyai asumsi bahwa semua tingkah laku baik adaptif maupun maladaptif dapat dipelajari. Belajar merupakan cara efektif untuk mengubah tingkah laku maladaptif. Selain itu kecanduan smartphone berkaitan langsung dengan disiplin diri dan layanan ini dapat dilakukan secara lebih mendalam kepada individu yang bersangkutan. Teknik yang digunakan oleh peneliti adalah teknik behavior contract. Teknik behavior contract yaitu kesepakatan tertulis antara dua orang individu atau lebih dimana salah satu atau kedua orang sepakat untuk terlibat dalam sebuah perilaku target (Miltenberger, 2007 dalam Erford, 2016).

Berdasarkan penjelasan tersebut konseling kelompok teknik behavior contract dapat menjadi alternatif dalam upaya mengurangi kecanduan smartphone yang dialami oleh siswa sekolah menengah pertama. Behavior contract memberikan peluang kepada siswa untuk memilih perilakunya sendiri yang akan diubah atas hasil persetujuan yang dilakukan bersama konselor dalam upaya mengubah perilaku yang tidak baik (maladaptif) sehingga siswa memiliki hak istimewa yang diharapkan dapat bertanggungjawab atas apa yang mereka sepakati.

Hal ini didukung dengan penelitian terdahulu mengenai pemanfaatan layanan konseling kelompok. Prasetiawan (2016) dalam penelitiannya menunjukkan bahwa konseling kelompok dapat mereduksi kecanduan games online siswa. Penelitian tersebut menyimpulkan bahwa konseling kelompok dapat menurunkan kecanduan games online siswa, hasil angket penelitian menunjukkan bahwa sebelum siswa diberi tindakan berada pada kategori tinggi, yaitu dengan jumlah frekuensi 10 sebesar 100\%, namun setelah diberi tindakan berada pada kategori sedang dengan frekuensi 3 sebesar $30 \%$, dan diikuti kategori rendah dengan frekuensi 7 sebesar $70 \%$.

Tujuan penelitian untuk menganalisis tingkat gejala-gejala kecanduan smartphone siswa sebelum dilakukan konseling kelompok teknik behavior contract, menganalisis mengetahui tingkat gejala-gejala kecanduan smartphone siswa sesudah dilakukan konseling kelompok teknik behavior contract, dan menguji konseling kelompok dengan teknik behavior contract efektif dalam mengurangi gejala-gejala kecanduan smartphone pada siswa kelas VIII di SMPN 2 Ungaran.

\section{METODE}

Peneliti menggunakan penelitian eksperimen pre-eksperimental design. Desain ini belum merupakan eksperimen sungguh-sungguh, karena masih terdapat variabel yang ikut berpengaruh terhadap terbentuknya variabel dependen. Tidak adanya variabel kontrol dan sampel tidak dipilih secara random. Bentuk dari penelitian ini adalah onegroup pretest-posttest design yaitu desain yang membandingkan keadaan sebelum dan sesudah diberi perlakuan agar diketahui hasil yang lebih akurat. Metode ini diberikan kepada satu kelompok saja tanpa ada kelompok pembanding. Subjek dalam penelitian ini diambil bagian dari populasi yaitu keseluruhan siswa kelas VIII SMPN 2 Ungaran yang berjumlah 287 siswa dari delapan kelas yang ada. Peneliti mengambil 7 siswa 
terpilih yang memiliki tingkat kecanduan smartphone paling tinggi (dari data awal) untuk melaksanakan pretest sebagai subjek penelitian atau responden konseling kelompok teknik behavior contract. Penelitian ini menggunakan sampel sumber data terpilih, yaitu dengan teknik purposive sampling.

Langkah-langkah yang dilakukan dalam penelitian ini diantaranya adalah penyusunan kisi-kisi instrumen, uji coba instrumen,melakukan revisi terhadap instrumen yang belum valid, pelaksanaan perlakuan di lapangan dan melakukan analisis sehingga diperoleh hasil penelitian. Intrumen dalam penelitian ini menggunakan skala kecanduan smartphone. Pengujian validitas skala kecanduan smartphone dilakukan dengan menggunakan uji product moment dan reliabilitas instrumen ditentukan dengan uji alpha cronbach. Uji hipotesis dilakukan dengan mengguakan analisis data deskriptif persentase, dan analisis inferensial uji wilcoxon.

\section{HASIL DAN PEMBAHASAN}

Gambaran tingkat gejala kecanduan smartphone siswa kelas VIII di SMPN 2 Ungaran sebelum diberikan konseling kelompok teknik behavior contract berada pada kateori tinggi. Hasil kategori tingkatan gejala kecanduan smartphone dapat dilihat pada Tabel 1 berikut:

Tabel 1. Distribusi Frekuensi Kecanduan Smartphone Sebelum Treatmen

\begin{tabular}{cccc}
\hline Interval & $F$ (Pretest) & Persentase & Kriteria \\
\hline $218,4-260$ & - & $84 \%-100 \%$ & Sangat Rendah \\
$176,8-217,4$ & - & $68 \%-83 \%$ & Rendah \\
$135,2-175,8$ & 3 & $52 \%-667 \%$ & Sedang \\
$93,6-134,2$ & 4 & $36 \%-51 \%$ & Tinggi \\
$52-92,6$ & - & $20 \%-35 \%$ & Sangat Tinggi \\
\hline Jumlah & 7 & & \\
\hline
\end{tabular}

Berdasarkan tabel 1 persentase hasil perhitungan skala kecaduan smartphone di atas, dapat diketahui bahwa gejala-gejala kecanduan smartphone pada siswa kelas VIII di SMPN 2 Ungaran masih ada siswa yang memiliki kecanduan smartphone tinggi. Rincian siswa dalam tabel 1 yaitu 3 siswa memiliki kecanduan smartphone sedang, dan 4 siswa memiliki kecanduan smartphone tinggi. Jumlah siswa yang mengikuti konseling kelompok yaitu sebanyak 7 siswa (anggota kelompok). Berikut disajikan hasil pretest 7 siswa yang menjadi anggota konseling kelompok :

Tabel 2. Hasil Perhitungan Kecanduan Smartphone Pre-test Anggota Kelompok

\begin{tabular}{lcccc}
\hline No & Responden & Skor & Persentase & Kriteria \\
\hline 1 & AN & 139 & $53,46 \%$ & Sedang \\
2 & DV & 148 & $56,92 \%$ & Sedang \\
3 & HP & 122 & $46,92 \%$ & Tinggi \\
4 & NB & 113 & $43,46 \%$ & Tinggi \\
5 & FT & 135 & $51,92 \%$ & Tinggi \\
6 & AT & 120 & $46,15 \%$ & Tinggi \\
7 & AR & 144 & $55,38 \%$ & Sedang \\
\hline
\end{tabular}

Hasil pre-test siswa kelas VIII di SMP Negeri 2 Ungaran yang kemudian dipilih sebagai anggota kelompok yang akan diberi konseling kelompok dengan teknik behavior contract. Siswa yang dipilih menjadi anggota kelompok didominasi oleh siswa yang 
memiliki tingkat gejala kecanduan smartphone tinggi. Dari 7 siswa, 4 siswa tergolong dalam kriteria gejala kecanduan smartphone tinggi sedangkan 3 siswa lainnya tergolong dalam kriteria gejala kecanduan smartphone sedang. Skor rata-rata dari 7 orang siswa tersebut yaitu sebesar 131, 57 dengan prosentase sebesar 50,60\% yang termasuk dalam kategori tinggi. Siswa yang dipilih untuk menjadi anggota konseling kelompok terdiri dari 1 siswa laki-laki dan 6 siswa perempuan.

Setelah dilaksanakan treatment berupa layanan konseling kelompok menggunakan teknik behavior contract sebanyak enam kali pertemuan, selanjutnya dilakukan post-test untuk mengetahui ada atau tidaknya penurunan tingkat gejala kecanduan smartphone pada siswa kelas VIII. Hasil post-test dapat dilihat pada tabel 3.

Tabel 3. Hasil Post-Test Kecanduan Smartphone Anggota Kelompok

\begin{tabular}{ccccc}
\hline No & Responden & Skor & Prosentase & Kriteria \\
\hline 1 & AN & 182 & $70,00 \%$ & Rendah \\
2 & DV & 186 & $71,53 \%$ & Rendah \\
3 & HP & 177 & $68,07 \%$ & Rendah \\
4 & NB & 163 & $62,69 \%$ & Sedang \\
5 & FT & 186 & $71,53 \%$ & Rendah \\
6 & AT & 172 & $66,15 \%$ & Sedang \\
7 & AR & 186 & $71,53 \%$ & Rendah \\
\hline
\end{tabular}

Berdasarkan hasil post-test pada tabel 4 dapat diketahui bahwa, dari 7 siswa yang telah mengikuti konseling kelompok menggunakan teknik behavior contract diperoleh jumlah skor rata-rata sebesar 178,85 dan prosentase sebesar $68,79 \%$. Skor rata-rata yang diperoleh termasuk dalam kategori kecanduan smartphone rendah. Perbandingan hasil pretest dan post-test dimaksudkan untuk mengetahui perbedaan gejala kecanduan smartphone antara sebelum dan sesudah diberi treatment berupa konseling kelompok menggunakan teknik behavior contract. Perbandingan hasil pre-test dan post-test tersebut dapat dilihat pada tabel 4.

Tabel 4.

Hasil Perbandingan Pre-test dan Post-test Konseling Kelompok dengan Teknik Behavior Contract

\begin{tabular}{|c|c|c|c|c|c|c|c|c|c|}
\hline \multirow{2}{*}{ No } & \multirow{2}{*}{$\mathbf{R}$} & \multicolumn{3}{|c|}{ Hasil Pre-test } & \multicolumn{3}{|c|}{ Hasil Post-test } & \multicolumn{2}{|c|}{ Penurunan } \\
\hline & & Skor & $\%$ & Kriteria & Skor & $\%$ & Kriteria & Skor & $\%$ \\
\hline 1 & AN & 139 & 53,46 & Sedang & 182 & 70 & Rendah & 43 & 16,53 \\
\hline 2 & DV & 148 & 56,92 & Sedang & 186 & 71,53 & Rendah & 38 & 14,61 \\
\hline 3 & HP & 122 & 46,92 & Tinggi & 177 & 68,07 & Rendah & 55 & 21,15 \\
\hline 4 & NB & 113 & 43,46 & Tinggi & 163 & 62,69 & Sedang & 50 & 19,23 \\
\hline 5 & FT & 135 & 51,92 & Tinggi & 186 & 71,53 & Rendah & 51 & 19,16 \\
\hline 6 & AT & 120 & 46,15 & Tinggi & 172 & 66,15 & Sedang & 52 & 20 \\
\hline 7 & $\mathrm{AR}$ & 144 & 55,38 & Sedang & 186 & 71,53 & Rendah & 42 & 16,15 \\
\hline \multicolumn{2}{|c|}{ Rata-rata } & 131,57 & 50,60 & Tinggi & 178,85 & 68,79 & Rendah & 42,28 & 18,18 \\
\hline
\end{tabular}


Dari data tersebut dapat diketahui bahwa kecanduan smartphone siswa kelas VIII di SMP Negeri 2 Ungaran mengalami mengalami penurunan gejala-gejala kecanduan smartphone, baik secara individu maupun kenaikan rata-rata secara keseluruhan. Skor ratarata gejala kecanduan smarphone siswa sebelum diberi konseling kelompok yaitu sebesar 131,57 dengan prosentase 50,60\%, kemudian setelah diberi konseling kelompok skor bertambah menjadi sebesar 178,85 dengan presentase sebesar $68,79 \%$. Perubahan atau penurunan skor rata-rata tersebut sebesar 42,28 atau sebesar $18,18 \%$. Skor rata-rata awal sebelum mendapatkan termasuk dalam kategori gejala kecanduan smartphone tinggi, kemudian setelah konseling kelompok diberikan kategori gejala kecanduan smartphone siswa berubah menjadi kategori rendah.

Selanjutnya berdasarkan hasil uji Wilcoxon diperoleh nilai $\mathrm{Z}$ hitung -2,366, dan asymp signifikansi 0,018 lebih kecil dari p tabel $0.05(\mathrm{z}=-2,366, \mathrm{p}<0.05)$. Dengan demikian dapat diartikan bahwa konseling kelompok dengan teknik behavior contract efektif untuk mengurangi gejala-gejala kecanduan smartphone pada siswa Kelas VIII di SMPN Ungaran.

Gejala kecanduan smartphone merupakan perilaku dimana seseorang mengalami keinginan lebih atau ketergantungan terhadap smartphone. Berdasarkan aspek-aspek seseorang yang mengalami kecanduan smartphone yang meliputi (1) daily life disturbance, (2) positive anticipation, (3) withdrawal, (4) cyberspace-oriented relationship, (5) overuse, dan (6) tolerance, maka hasil analisis penelitian tingkat gejala kecanduan smartphone pada ketujuh siswa sebelum diberikan menunjukkan dengan nilai rata-rata tinggi. Indikator yang menunjukkan kategori paling tinggi adalah withdrawal atau menarikan diri dari lingkungan sosial dan memiliki emosi yang tak terkendali. Penelitian Consetta (2015), menjelaskan bahwa remaja menghabiskan waktu lebih banyak didepan smartphone dan internet selain untuk berkomunikasi, mereka juga merasa bebas dari kecemasan dan ketakutan, dan juga para remaja memanfaatkan smartphone sebagai sarana untuk melarikan diri dari dunia nyata, ketika siswa kesulitan beradaptasi di lingkungan sekolah atau masyarakat dan mereka diterima di dunia maya, maka mereka cenderung suka melarikan diri dari lingkungan sekitar.

Berdasarkan hasil analisis tersebut, dari ketujuh anggota konseling kelompok teknik behavior contract, enam anggota adalah perempuan dan satu anggota adalah laki-laki. Park dan Lee (2014) menyatakan bahwa perempuan memiliki resiko perilaku kecanduan smartphone lebih tinggi dari pada laki-laki. Setelah diberikan konseling kelompok teknik behavior contract nilai rata-rata siswa dalam kategori rendah. Konseling kelompok merupakan suatu upaya pemberian bantuan kepada individu (konseli) yang dilakukan dalam suasana kelompok, bersifat pencegahaan dan penyembuhan, serta bertujuan untuk memberikan kemudahan dalam berbagai aspek perkembangan dan pertumbuhan (Rusmana, 2009).

Teknik yang dipakai dalam konseling kelompok ini yaitu teknik behavior contract. Teknik behavior contract adalah kesepakatan tertulis antara dua orang individu atau lebih dimana salah satu atau kedua orang sepakat untuk terlibat dalam sebuah perilaku target (Miltenberger, 2007 dalam Erford, 2016). Dari ketujuh siswa di bimbing untuk dapat menuliskan kontrak berisikan tentang perubahan perilaku ke arah yang lebih baik berkaitan dengan gejala kecanduan smartphone yang mereka miliki supaya dapat berkurang. Setelah mereka menulis kontrak kemudian ditandatangani dan disepakati oleh peneliti (konselor) dan siswa, didalam kontrak tersebut ada batas tanggal pelaksanaan kontrak sesuai kesepakatan dan tidak pula memberikan penghargaan apabila perilaku telah tercapai. Seperti yang dikatakan Wahyuni (2016) bahwa behavior contract merupakan suatu 
perjanjian antara anak dengan guru baik secara lisan maupun tulisan untuk berperilaku tertentu dan akan diberikan penghargaan. Penggunaan teknik behavior contract karena tingkah laku dapat dipelajari dan dapat diubah dengan memberikan penguatan segera setelah tingkah laku yang diharapkan itu muncul.

Setelah diberikan perlakuan berupa konseling kelompok teknik behavior contract tingkat gejala kecanduan smartphone mengalami penurunan, semula dari kategori tinggi kemudian menjadi kategori rendah. Ketujuh siswa mengalami perubahan yang cukup baik. Siswa berinisial NB dan AT yang semula tingkat kecanduan smartphone berapa pada kategori tinggi, setelah mengikuti layanan konseling kelompok teknik behavior contract berada pada tingkat kategori sedang. Siswa berinisial HP dan FT yang semula tingkat kecanduan smartphone berada pada kategori tinggi, setelah diberikan konseling kelompok behavior contract berada pada ketegori sedang. Kemudian untuk siswa berinisial AN dan AR semula memiliki tingkat gejala kecanduan smartphone pada kategori sedang, setelah mengikuti konseling kelompok teknik behavior contract berada pada kategori rendah. Sehingga dapat disimpulkan bahwa dengan diberikan konseling kelompok teknik behavior contract dapat menurunkan tingkat gejala kecanduan smartphone siswa. Hal ini sesuai dengan penelitian Dewi dan Pratiwi (2016) menjelaskan bahwa konseling kelompok dengan teknik behavior contract dapat menurunkan perilaku seseorang.

Sejalan dengan penelitian Astriana, dkk (2016) yang menjelaskan bahwa dengan melaksanakan layanan konseling kelompok teknik behavior contract dengan baik maka dapat secara efektif menurunkan permasalahan penggunaan smartphone siswa. Sehingga konseling kelompok dengan teknik behavior contract dapat mengurangi kecanduan smartphone yang dialami oleh siswa.

Berdasarkan dari hasil analisis deskriptif, hasil observasi langsung saat pelaksanaan konseling kelompok, dan dari hasil analisis uji Wilcoxon semuanya menunjukan adanya perubahan positif pada siswa kelas VIII di SMPN 2 Ungaran. Perubahan positif tersebut yaitu penurunan gejala-gejala kecanduan smartphone siswa kelas VIII yang menjadi anggota kelompok setelah mendapatkan treatment berupa konseling kelompok dengan teknik behavior contract.

\section{PENUTUP}

Berdasarkan hasil penelitian dapat disimpulkan bahwa Pertama Gejala-gejala kecanduan smartphone pada siswa kelas VIII di SMPN 2 Ungaran sebelum mendapatkan konseling kelompok dengan teknik behavior contract termasuk dalam kategori tinggi. Kedua gejala-gejala kecanduan smartphone pada siswa kelas VIII di SMPN 2 Ungaran sesudah mendapatkan konseling kelompok dengan teknik behavior contract termasuk dalam kategori rendah. Ketiga konseling kelompok dengan teknik behavior contract terbukti efektif untuk mengurangi gejala-gejala smartphone pada siswa kelas VIII di SMPN 2 Ungaran. Walaupun penelitian ini mampu membuktikan bahwa konseling kelompok dengan teknik behavior contract efektif untuk mengurangi gejala-gejala smartphone, namun penelitian ini terbatas pada siswa kelas VIII belum mencakup keseluruhan tingkat kelas serta masih mengukur pada satu kelompok dan tanpa melihat perbedaan jenis kelamin. Penelitian selanjutnya diharapkan mencakup siswa di berbagai tingkatan kelas dan menggunakan desain penelitian yang lebih kompleks dan. mempertimbangkan perbedaan jenis kelamin 


\section{DAFTAR PUSTAKA}

Astriana, Abdul Munir \& Ridwan Syahran. 2016. Efektivitas Layanan Konseling kelompok Teknik Behavior Contract dalam Mengurangi penyalahgunaan Smartphone siswa kelas XI Jurusan Administrasi perkantoran (AP) SMK Negeri 2 Palu. Jurnal konseling \& Psikoedukasi. Vol. 1. No. 2. 15-29.

Alwilsol. 2007. Psikologi Kepribadian. Malang: Universitas Muhammadiyah Malang Press.

Concetta de Pasquale, Federica.S, \& Zira Hichy. 2015. Smartphone Addiction and Dissociative Experience: An invertigation in Italian adolescents aged between 14 and 19 years. Psychology \& Behavior Analysis. Vol.1 No 2. 109.

Corey, Gerald. 2005. Teori dan Praktik Konseling dan Psikoterapi. Bandung: PT. Refika Aditama.

Dewi, Ovilla Priska dan Titin Indah Pratiwi. 2016. Penerapan Konseling Kelompok dengan Teknik Behavior Contract untuk Mengurangi Perilaku membolos pada siswa di SMK Kamang 2 Surabaya. Jurnal BK UNESA. 6(3).

Erford, B. T. 2016. 40 Teknik yang Harus diketahui Setiap Konselor (Edisi Kedua) Terjemahan oleh Helly Prajitno Soetjipto \& Sri Mulyantini Soetjipto. Yogyakarta: Pustaka Pelajar.

Iskandar, I. 2011. Motif Mahasiswa untuk Menggunakan Ponsel Pintar di Surabaya. Surabaya: Universitas Pembangunan Nasional "Veteran" Surabaya.

Jeewon, Lee, dkk. 2016. Psychological Factors Associated With Smartphone Addiction in South Korean Adolescents. Journal of Early Adolescence, 1-15.

Kurniawan, A. \& Cahyati, I.Y. 2013. Hubungan antara Academic Stress dengan Smartphone Addiction pada Mahasiswa Pengguna Smartphone. Jurnal Psikologi dan Kesehatan Mental.2(1).

Kwon, M., Kim, D.-J., Cho, H., \& Yang, S. 2013. The smartphone addiction scale: Development and validation of a short version for adolescents. PloS ONE, 8(12), e83558.

Masruri. 2011. Negative Learning. Solo: Era Adicipta.

Park, N., \& Lee, H. 2014. Nature Of Youth Smartphone Addiction In Korea. Media Information Resarch. 51(1). 100-132

Prasetiawan, Hardi. 2016. Upaya Mereduksi Games Online Melalui Konseling kelompok. Jurnal Fokus Konseling. Vol 2. No.2. 116-125.

Rusmana, Nandang. 2009. Bimbingan dan Konseling Kelompok di Sekolah. (Metode, Teknik dan Aplikasi). Bandung: Press.

Sparks, Glenn, G. 2013. Media Effects research, A Basic Overview, $4^{\text {th }}$ edt. USA: Wadsworth. Diakses melalui laman https://www.cjconline.ca/index.php/journal/article/download/2949/260.

Wahyuni, Novan Ardy. 2013. Save Our Chilrdern From School Bullying. Jogyakarta : ArRuzz.

Wibowo, Mungin Eddy. 2005. Konseling Kelompok Perkembangan. Semarang: Unnes Press. 